\title{
STRENGTH DEVELOPMENT OF CONCRETE WITH FLY ASH ADDITION
}

\author{
Marta Kosior-Kazberuk ${ }^{1}$, Małgorzata Lelusz ${ }^{2}$ \\ Bialystok Technical University, Wiejska 45 E, 15-351 Bialystok, Poland \\ E-mail:1'm.kosior@pb.bialystok.pl,2m.lelusz@pb.bialystok.pl \\ Received 1 Dec 2005; accepted 5 Dec 2006
}

\begin{abstract}
Based on experimental results, mathematical models were elaborated to predict the development of compressive strength of concrete with fly ash replacement percentages up to $30 \%$. Strength of concrete with different types of cement (CEM I 42.5, CEM I 32.5, CEM III 32.5), after 2, 28, 90, 180 days of curing, have been analysed to evaluate the effect of addition content, the time of curing and the type of cement on the compressive strength changes. The adequacy of equations obtained was verified using statistical methods. The test results of selected properties of binders and hardened concrete with fly ash are also included. The analysis showed that concrete with fly ash is characterised by advantageous applicable qualities.
\end{abstract}

Keywords: concrete, fly ash, compressive strength development, pozzolanic reaction, statistical methods, mathematical model.

\section{Introduction}

The incorporation of industrial by-products such as fly ash, slag, silica fume in concrete can significantly enhance its basic properties in both the fresh and hardened states $[1,2]$. These materials greatly improve the durability of concrete through control of high thermal gradients, pore refinement, depletion of cement alkalis, resistance to chloride and sulphate penetration, and continued microstructural development through a long-term hydration and pozzolanic reaction [3, 4]. The utilisation of by-products as the partial replacement of cement has important economical, environmental and technical benefits such as the reduced amount of waste materials, cleaner environment, reduced energy requirement, durable service performance during service life and costeffective structures.

It is well known that blending cement with fly ash or other supplementary cementing materials improves the reological properties of the fresh concrete and the engineering properties of hardened concrete [5-8]. These improvements are generally attributed to both the physical and chemical effects. The physical process is due to the particles fineness of the supplementary cementing materials that are much smaller than that of the cement, thereby providing densely packed particles between fine aggregates and cement grains, and, hence, the reduction in porosity. The chemical process is due to the activation of the non-crystalline silica, the major constituent of fly ash, by the calcium hydroxide produced from the hydrating cement to form secondary calcium silicate hydrate that also fills the pore spaces and further reduces the porosity. Factors such as the origin of the coal and burning conditions, strongly affect fly ashes chemical and mineralogical compositions.
The present paper deals with the concrete containing supplementary cementing material: fly ash. Because of the wide availability and low cost, coal fly ashes are the most commonly used in the manufacture of cement-based materials to improve their microstructure $[9,10]$. The compressive strength-developing behaviour of concrete containing fly ash widely differs from that of concrete without fly ash depending on the method and amount of fly ash addition [11-13]. The rate of strength increase of fly ash concrete is slower but it is sustained for longer periods than the rate of the strength increase of portland cement concrete $[14,15]$. Due to this fact the research programme concerning relationships between composition of concrete and its compressive strength development has been realised.

It is considered highly useful to establish the proportioning technique for concrete containing fly ash to derive an equation to quantitatively estimate the compressive strength development of such concrete. Some studies on determining the optimal content of fly ash, for obtaining concrete with a required mechanical strength, have been presented in the paper. The quality of model, defined as the relationship between properties and addition content and time of curing, was evaluated.

\section{Experimental investigation}

\subsection{Materials}

Tests were carried out for concretes contained three types of commercial cement: two sorts of Portland cement CEM I 42.5 R (C1), CEM I 32.5 R (C2) with different mineral composition and blast-furnace cement CEM III/A 32.5 NA (C3). The mineralogical composition of clinkers in cements used is presented in Table 1 . The blast 
furnace slag used in cement $\mathrm{C} 3$ contained $44,8 \% \mathrm{CaO}$; $39,1 \% \quad \mathrm{SiO}_{2} ; 7,1 \% \mathrm{Al}_{2} \mathrm{O}_{3} ; 1,7 \% \mathrm{Fe}_{2} \mathrm{O}_{3} ; 0,23 \% \quad \mathrm{SO}_{3}$; $6,2 \% \mathrm{MgO}$. The content of slag in cement $\mathrm{C} 3$ was $62 \%$.

Table 1. Mineralogical composition of clinkers in cements used

\begin{tabular}{l|c|c|c|c}
\hline \multirow{2}{*}{\multicolumn{1}{c|}{ Clinker }} & \multicolumn{4}{c}{ Content in mass, \% } \\
\cline { 2 - 5 } & $\mathrm{C}_{3} \mathrm{~S}$ & $\mathrm{C}_{2} \mathrm{~S}$ & $\mathrm{C}_{3} \mathrm{~A}$ & $\mathrm{C}_{4} \mathrm{AF}$ \\
\hline $\mathrm{C} 1$ and C3 cement & 62,1 & 14,5 & 8,6 & 9,3 \\
\hline $\mathrm{C} 2$ cement & 60,4 & 15,5 & 9,1 & 8,8 \\
\hline
\end{tabular}

The fine aggregate used was river sand with a maximum diameter of $2 \mathrm{~mm}$, the coarse aggregate - basalt grit with a maximum diameter of $8 \mathrm{~mm}$.

Fly ash from local power plant was used. It was obtained in high temperature process. The phase composition of it was determined by diffractional X-ray analysis (Fig 1). Two main crystalline phases: $\beta$-quartz and mullite were determined. The fly ash also contained anhydrite, calcium oxide, and a very little amount of calcite and gypsum. The content of $\mathrm{CaO}$ (free), obtained from analytical test, was $0,25 \%$.

The loss of ignition, monitored every $8 \mathrm{~h}$ during 25 days, did not exceed $4,8 \%$. The specific gravity of mineral addition was $2,23 \mathrm{~kg} / \mathrm{dm}^{3}$.

\subsection{Properties of binders}

Pozzolanic activity of fly ash [16] was evaluated according to standard PN-EN 450:1998 [17]. Its index was determined on the basis of the comparison of compressive $\left(f_{c m}\right)$ as well as flexural strength $\left(f_{t m}\right)$ of mortars containing $75 \%$ of cement and $25 \%$ of fly ash, and mortar without addition. The results of pozzolanic activity are presented in Tables 2, 3 .

Table 2. The results of pozzolanic activity of fly ash, determined on the basis of mortar compressive strength $f_{c m}$

\begin{tabular}{c|c|c|c|c}
\hline \multirow{2}{*}{$\begin{array}{c}\text { Pozzolanic activity } \\
\text { index based on } f_{c m}\end{array}$} & \multirow{2}{*}{$\begin{array}{c}\text { Require- } \\
\text { ments, \% }\end{array}$} & \multicolumn{3}{|c}{ Cement sort, \% } \\
\cline { 3 - 5 } & & $\mathrm{C} 1$ & $\mathrm{C} 2$ & $\mathrm{C} 3$ \\
\hline after 28 days & $>75$ & 95 & 81 & 85 \\
\hline after 90 days & $>85$ & 106 & 106 & 90 \\
\hline
\end{tabular}

The required values of the pozzolanic activity index, according to [17], were gained in the case of portland cements (C1 and $\mathrm{C} 2)$ as well as blastfurnace cement $(\mathrm{C} 3)$.

Table 3. The results of pozzolanic activity of fly ash, determined on the basis of mortar flexural strength $f_{t m}$

\begin{tabular}{c|c|c|c|c}
\hline \multirow{2}{*}{$\begin{array}{c}\text { Pozzolanic activity } \\
\text { index based on } f_{\text {tm }}\end{array}$} & \multirow{2}{*}{$\begin{array}{c}\text { Require- } \\
\text { ments, \% }\end{array}$} & \multicolumn{3}{|c}{ Cement sort, \% } \\
\cline { 3 - 5 } & & $\mathrm{C} 1$ & $\mathrm{C} 2$ & $\mathrm{C} 3$ \\
\hline after 28 days & $>75$ & 93 & 87 & 90 \\
\hline after 90 days & $>85$ & 94 & 93 & 103 \\
\hline
\end{tabular}

The test results of water requirement in order to get normal consistency of cement paste are presented in Fig 2. It was established that the increase in fly ash content, related to cement mass, causes the increase in water requirement, due to a large specific surface of fly ash.

The setting times of cement paste with fly ash were determined using Vicat needle, according to PN-EN 196-3: 1996 [18]. As it is shown in Figs 3, 4, 5, the setting times are prolonged, a little in the case of $\mathrm{C} 1$ and $\mathrm{C} 2$ cement and significantly in case of $\mathrm{C} 3$ cement, with increasing fly ash content in the paste. However, the effect of fly ash on setting time should be analysed considering the amount of water required to get a normal consistency. The greater water content, the longer setting time.

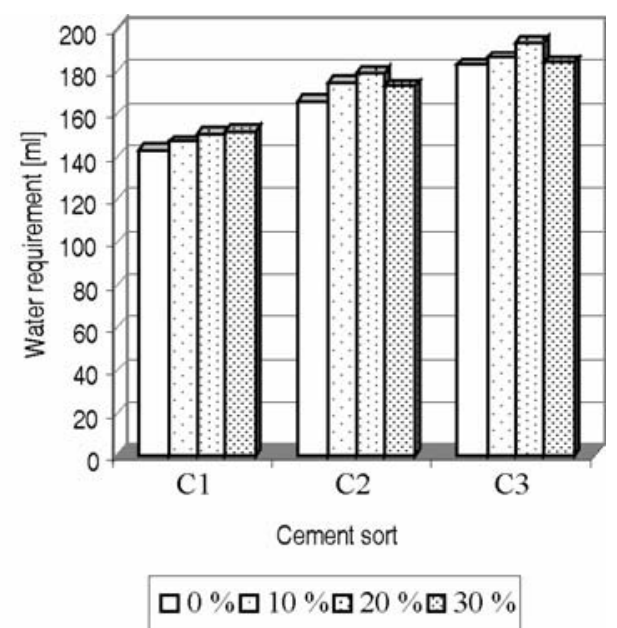

Fig 2. Relationships between water required for getting normal consistency and fly ash amount replacing cement

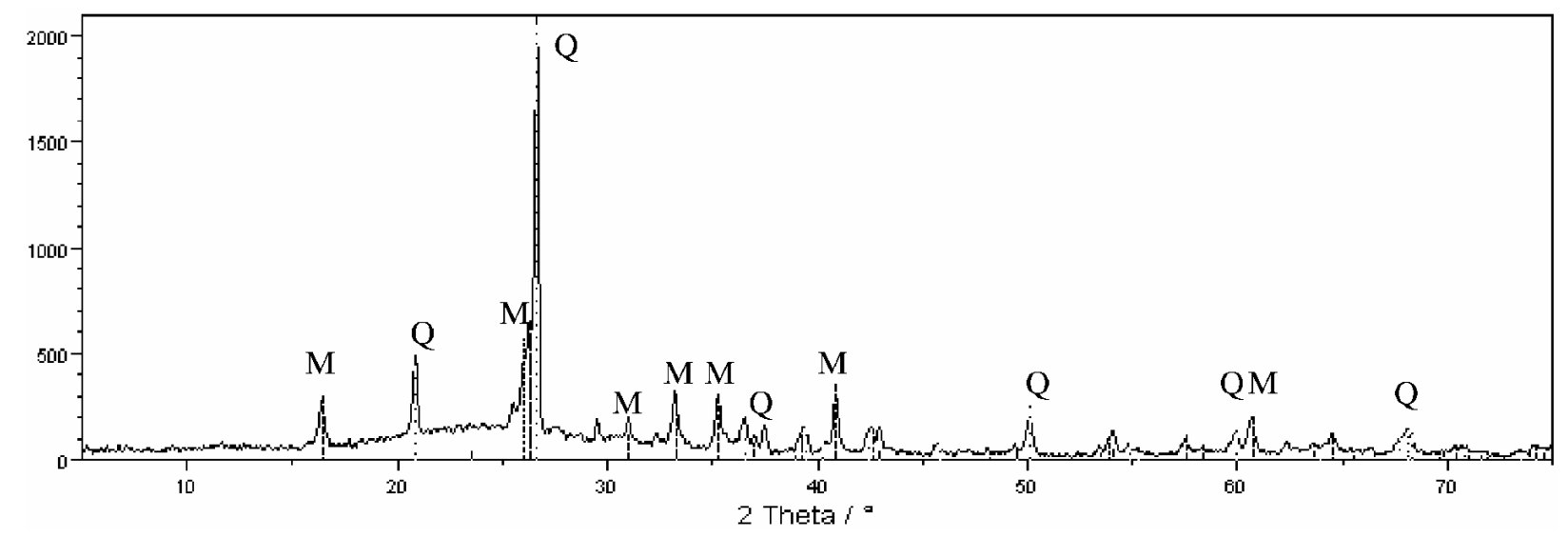

Fig 1. X-ray pattern of fly ash used $(\mathrm{M}-$ mullite, $\mathrm{Q}-\beta$-quartz) 


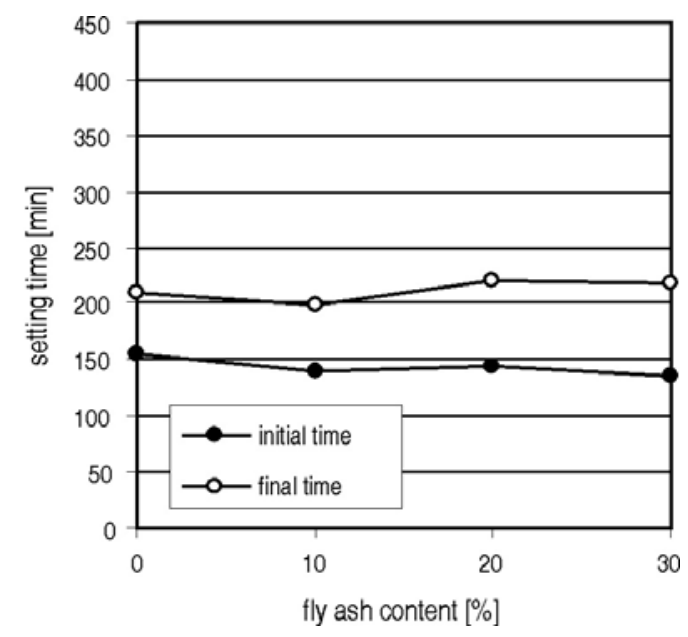

Fig 3. Setting times vs fly ash content in the paste with $\mathrm{C} 1$ cement

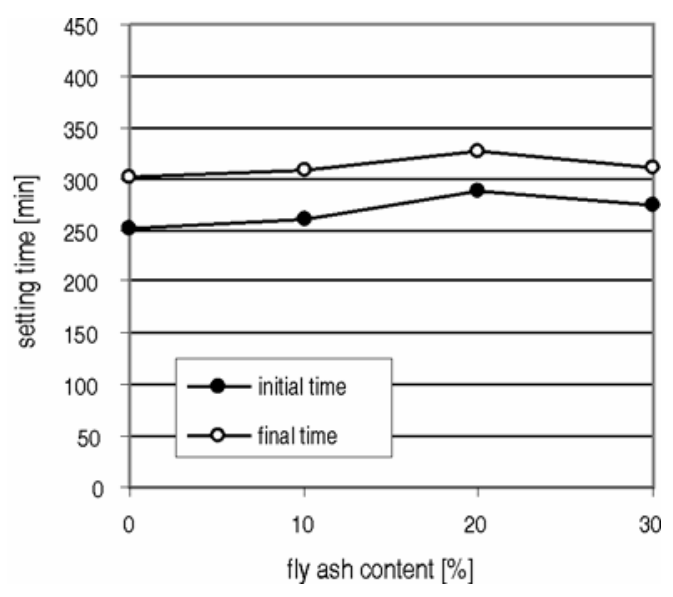

Fig 4. Setting times vs fly ash content in the paste with $\mathrm{C} 2$ cement

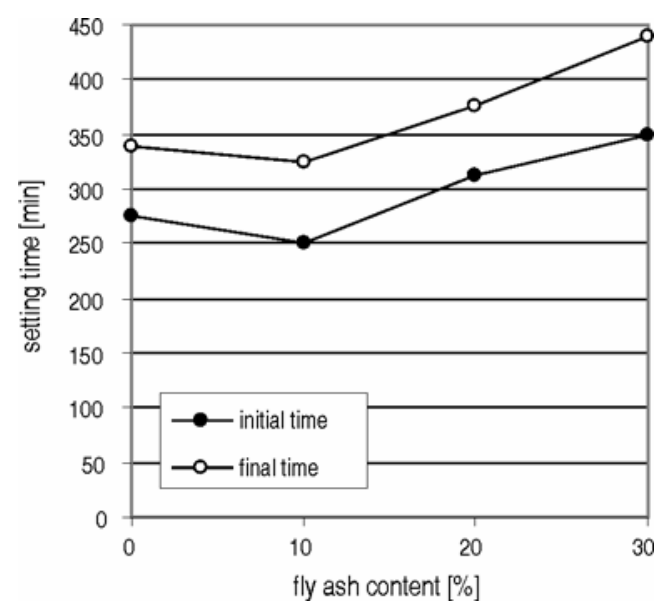

Fig 5. Setting times vs fly ash content in the paste with $\mathrm{C} 3$ cement

The setting times of cement paste with fly ash were determined using Vicat needle, according to PN-EN 196-3: 1996 [18]. As it is shown in Figs 3, 4, 5, the setting times are prolonged, a little in the case of $\mathrm{C} 1$ and $\mathrm{C} 2$ cement and significantly in case of $\mathrm{C} 3$ cement, with in- creasing fly ash content in the paste. However, the effect of fly ash on setting time should be analysed considering the amount of water required to get a normal consistence. The greater water content, the longer setting time.

\subsection{Mix proportions}

Tests were carried out on concrete specimens prepared of mixtures with three different values of fly ash content: 10, 20 and $30 \%$ related to cement mass (FA/C), as well as on unmodified control specimens. The part of fly ash in mixture (40\% for CEM I 42,5 and $20 \%$ for CEM I 32,5 and CEM III/A 32,5) was taken into account as a binder and the remaining part - as filler, according to the standard EN 206-1:2003 [19]. The cement content in control concrete was $350 \mathrm{~kg} / \mathrm{m}^{3}$. A water to binder ratio in the tested concretes was constant $(w / b=0,50)$.

Concrete was cast in prism-shaped moulds $(40 \times 40 \times 160 \mathrm{~mm})$ and compacted by vibration. After 24 hours, the specimens were removed from the moulds and stored in water at of $18 \pm 2{ }^{\circ} \mathrm{C}$. The specimens were tested for compressive strength after 2, 28, 90 and 180 days of curing by the standard PN-EN 12390-3: 2002 [20]. Every series consisted of 6 replicates. The aim to apply the prism shaped specimens was to evaluate the compressive as well as the flexural strength. The latter strength was determined in a bending test and every series consisted of 3 replicates.

\section{Results and discussion}

\subsection{Selected properties of hardened concrete with fly ash}

The test results of the selected properties of concretes are summarised in Table 4.

Table 4. Selected properties of concretes with fly ash addition after 28 days of curing

\begin{tabular}{c|c|c|c|c}
\hline $\begin{array}{c}\text { Cement } \\
\text { sort }\end{array}$ & FA/C & $\begin{array}{c}\text { Specific } \\
\text { gravity, } \\
\mathrm{kg} / \mathrm{dm}^{3}\end{array}$ & $\begin{array}{c}\text { Water } \\
\text { absorption, } \\
\%\end{array}$ & $\begin{array}{c}\text { Capillary } \\
\text { suction, } \\
\%\end{array}$ \\
\hline \multirow{4}{*}{ C1 } & 0,0 & 2,74 & 4,70 & 1,44 \\
\cline { 2 - 5 } & 0,1 & 2,79 & 4,80 & 1,30 \\
\cline { 2 - 5 } & 0,2 & 2,72 & 4,90 & 1,22 \\
\cline { 2 - 5 } & 0,3 & 2,68 & 5,20 & 1,25 \\
\hline \multirow{4}{*}{ C2 } & 0,0 & 2,76 & 5,57 & 1,25 \\
\cline { 2 - 5 } & 0,1 & 2,70 & 5,01 & 1,33 \\
\cline { 2 - 5 } & 0,2 & 2,67 & 5,11 & 1,34 \\
\cline { 2 - 5 } & 0,3 & 2,74 & 5,41 & 1,29 \\
\hline \multirow{4}{*}{ C3 } & 0,0 & 2,73 & 5,52 & 1,59 \\
\cline { 2 - 5 } & 0,1 & 2,71 & 5,34 & 1,42 \\
\cline { 2 - 5 } & 0,2 & 2,68 & 5,57 & 1,36 \\
\cline { 2 - 5 } & 0,3 & 2,76 & 5,58 & 1,25 \\
\hline
\end{tabular}

The fly ash addition, in considered range of FA/C values, has no significant effect on specific gravity and water absorption. The addition reduces the capillary suction of water, determined after $24 \mathrm{~h}$ test.

The variation of flexural strength with curing time of concretes is presented in Figs 6-8. The results of flexural strength make it possible to evaluate the rate of strength 
increase. The graphs show that the rate of strength development of the concrete with fly ash is slower in comparison to that of the control specimens. The concretes containing additives reached greater values of flexural strength than control concretes. The changes in strength with age can be analysed in detail on the basis of percentage relative strength to 28 days strength, in Tables 5-7.

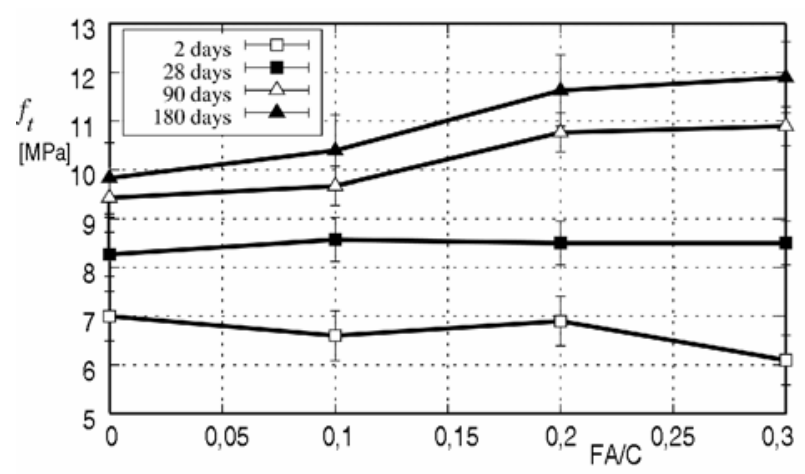

Fig 6. Flexural strength development of cement $\mathrm{C} 1$ concrete (vertical bars represent the range of accuracy)

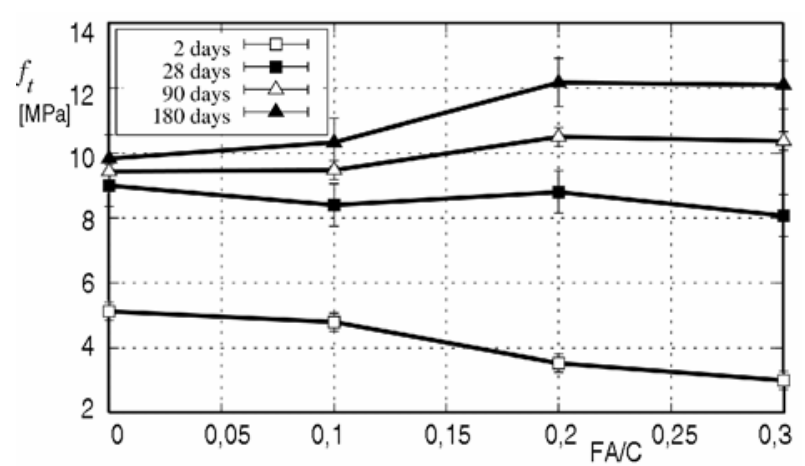

Fig 7. Flexural strength development of cement $\mathrm{C} 2$ concrete

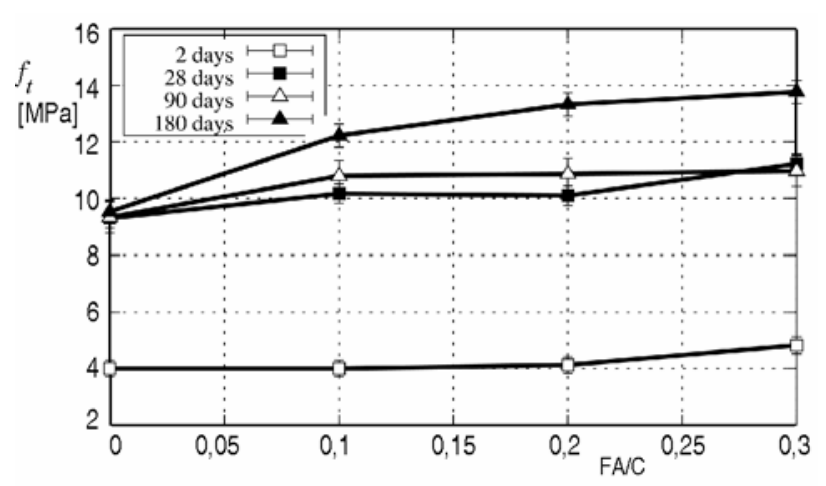

Fig 8. Flexural strength development of cement $\mathrm{C} 3$ concrete

Table 5. Flexural strength development of $\mathrm{C} 1$ cement concretes in relation to 28-days strength

\begin{tabular}{c|c|c|c|c}
\hline \multirow{2}{*}{ FA/C } & \multicolumn{4}{|c}{$\begin{array}{c}\text { Percentage relative strength } \\
\text { to 28-days strength, \% }\end{array}$} \\
\cline { 2 - 5 } & $2 \mathrm{~d}$ & $28 \mathrm{~d}$ & $90 \mathrm{~d}$ & $180 \mathrm{~d}$ \\
\hline 0,0 & 84 & 100 & 113 & 118 \\
\hline 0,1 & 77 & 100 & 113 & 121 \\
\hline 0,2 & 78 & 100 & 127 & 136 \\
\hline 0,3 & 70 & 100 & 122 & 140 \\
\hline
\end{tabular}

Table 6. Flexural strength development of $\mathrm{C} 2$ cement concretes in relation to 28-days strength

\begin{tabular}{c|c|c|c|c}
\hline \multirow{2}{*}{ FA/C } & \multicolumn{4}{|c}{$\begin{array}{c}\text { Percentage relative strength } \\
\text { to 28-days strength, \% }\end{array}$} \\
\cline { 2 - 5 } & $2 \mathrm{~d}$ & $28 \mathrm{~d}$ & $90 \mathrm{~d}$ & $180 \mathrm{~d}$ \\
\hline 0,0 & 57 & 100 & 104 & 109 \\
\hline 0,1 & 57 & 100 & 113 & 123 \\
\hline 0,2 & 40 & 100 & 119 & 139 \\
\hline 0,3 & 37 & 100 & 128 & 149 \\
\hline
\end{tabular}

Table 7. Flexural strength development of $\mathrm{C} 3$ cement concretes in relation to 28-days strength

\begin{tabular}{c|c|c|c|c}
\hline \multirow{2}{*}{ FA/C } & \multicolumn{4}{|c}{$\begin{array}{c}\text { Percentage relative strength } \\
\text { to 28-days strength, \% }\end{array}$} \\
\cline { 2 - 5 } & $2 \mathrm{~d}$ & $28 \mathrm{~d}$ & $90 \mathrm{~d}$ & $180 \mathrm{~d}$ \\
\hline 0,0 & 43 & 100 & 100 & 102 \\
\hline 0,1 & 39 & 100 & 106 & 120 \\
\hline 0,2 & 40 & 100 & 108 & 132 \\
\hline 0,3 & 42 & 100 & 100 & 123 \\
\hline
\end{tabular}

The observed results of concrete strength test prove fly ash influence on the strength development at all ages. It is found, in general, that the rate of strength development is lower for mixtures containing fly ash, at early ages. The rate of strength gain in concretes with fly ash is significant between 28 and 180 days. The mixtures with $\mathrm{C} 1$ cement achieve the highest one and the mixtures with C3 cement achieve the lowest 2-days flexural strength in comparison with 28-days strength because of cements used for composition. The increase in strength between 28 and 90 days of curing is the slowest for C3 cement (blastfurnace cement) concretes, but after 180 days of storage the flexural strength of C3 cement concretes with fly ash is comparable with $\mathrm{C} 2$ cement concretes.

\subsection{Analysis of compressive strength test results}

The test results of compressive strength of concrete containing fly ash are in Figs 9-11.

After 2 and 28 days of curing, the control concretes $(\mathrm{FA} / \mathrm{C}=0,0)$ attained higher strength values than the modified ones. The test results after 90 and 180 days of storage show that all mixes containing fly ash were able to develop a higher strength than the control mixes. The compressive strength of $\mathrm{C} 3$ cement concretes increased more slowly, but after 180 days attained the strength comparable with the strength of $\mathrm{C} 2$ cement concretes.

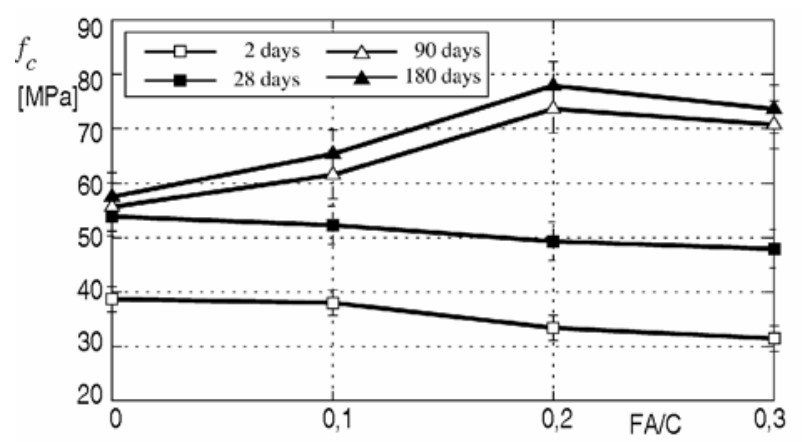

Fig 9. Compressive strength development of cement $\mathrm{C} 1$ concrete (vertical bars represent the range of accuracy) 


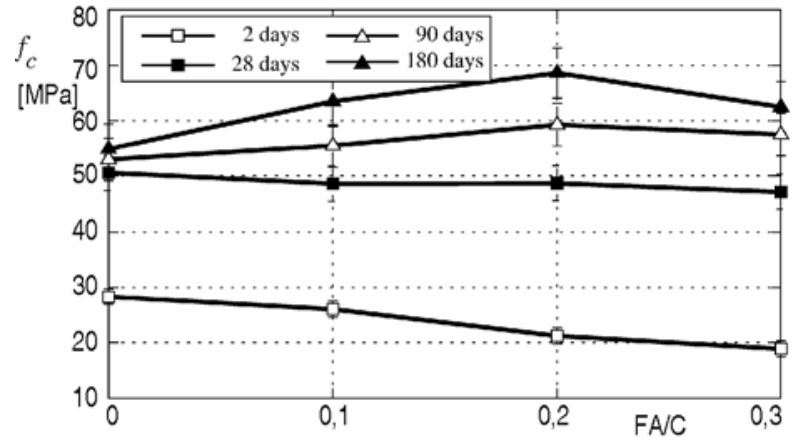

Fig 10. Compressive strength development of cement $\mathrm{C} 2$ concrete

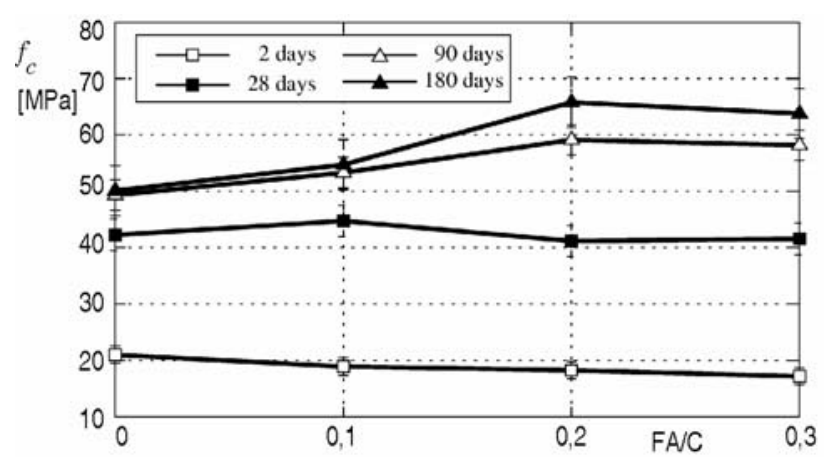

Fig 11. Compressive strength development of cement $\mathrm{C} 3$ concrete

The compressive strength test results were analysed using statistical methods.

The effects of FA/C value (factor $X_{1}$ ), time of curing $t$ (factor $X_{2}$ ) and type of cement (factor $X_{3}-$ qualitative) on the compressive strength of concrete $f_{c}$ (variable $Y$ ) have been studied using the method of analysis of variance. In this analysis, both the basic effects and the higher order interactions were analysed. For statistical interpretation of regression and analysis of variance it was assumed that the data was normally distributed.

Before the proper analysis, the Cochran's G test was used as a homogeneity test. The results of compressive strength test after 2, 28, 90 and 180 days of curing for 3 types of cement used were taken into account. The test showed that for 48 means and the degrees of freedom $d f=5$, the calculated value equals

$$
G_{i j k \max }=S_{i j k \max }^{2} / \Sigma S_{i j k}^{2}=0,0710,
$$

for level of significance $\alpha=0,05$ is less than admissible value $\mathrm{G}_{0,05,5,48}=0,0853$ [21], thus the compared variances are homogeneous and the test results are reproducible.
The analysis of variance was carried out in compliance with the procedure given in [21]. The analysis results are in Table 8 .

The F-Fisher test [21] was used to verify the hypothesis that $X_{1}, X_{2}$ and $X_{3}$ factors had the significant effect on compressive strength development. The influence of the individual factor or the interaction of factors is recognised as significant, if

$$
F_{\text {exp }}>F_{t a b}=F_{\alpha, f_{1}, f_{2}},
$$

where: $\alpha=0,05-$ level of significance, $f_{1}$, and $f_{2}-$ degrees of freedom.

As a result of the analysis of variance, presented in Table 8 , it has been found that individual factors and the first-order interactions as well as the second-order interaction have significant effect on the compressive strength development. Only the interaction of $X_{1}$ and $X_{3}$ factors has statistically insignificant effect.

For predicting compressive strength of concrete with fly ash, mathematical model describing the changes in strength $f_{c}$ (function $\hat{Y}$ ) in dependence on selected factors was developed.

Only the effect of the quantitative factors was taken into account: FA/C ratio (factor $X_{1}$ ) and the time of curing $t$ (factor $X_{2}$ ), separately for each type of cement.

For mathematical model elaboration of the following factors' levels, significant for practice, were selected:

- factor $X_{1}: 0,1 ; 0,2 ; 0,3$;

- factor $X_{2}: 2,28,90,180$ days.

As the function describing the compressive strength development, an orthogonal polynomial was assumed. The values of regression equation's coefficients were determined using the least-squares method. The calculations were conducted using the Data Analysis Programs STAT [22].

The relationship for the cement $\mathrm{C} 1$ concrete has been obtained as:

$\hat{Y}=36,986+4,725 X_{1} X_{2}-0,001324 X_{2}^{2}-10,87 X_{1}^{2} X_{2},(3)$ for the cement $\mathrm{C} 2$ concrete:

$\hat{Y}=29,871+4,519 X_{1} X_{2}-0,001099 X_{2}^{2}-10,92 X_{1}^{2} X_{2}$ and for the cement $\mathrm{C} 3$ concrete:

$\hat{Y}=24,639+4,989 X_{1} X_{2}-0,001411 X_{2}^{2}-11,47 X_{1}^{2} X_{2}$.

The significance of equation variables (according to t-Student criteria: if the calculated value $t_{c a l}$ is bigger than the critical value $t_{\alpha=0,05}$, the regression coefficient is significant), the multiple correlation coefficients and the determination coefficients are presented in Table 9.

Table 8. Analysis of variance results of $X_{1}, X_{2}, X_{3}$ factors influence on compressive strength of concrete

\begin{tabular}{c|c|c|c|c|c}
\hline Source of variation & Sums of squares & Degrees of freedom & Mean squares & $F_{\text {exp }}$ & $F_{\text {tab }}$ \\
\hline Factor $X_{1}$ & 1184,78 & 3 & 394,92 & 21,43 & 2,60 \\
\hline Factor $X_{2}$ & 59599,14 & 3 & 19866,38 & 1077,93 & 2,60 \\
\hline$X_{1}$ and $X_{2}$ & 4224,15 & 9 & 469,35 & 25,47 & 1,90 \\
\hline Factor $X_{3}$ & 6449,19 & 2 & 3224,60 & 174,96 & 2,99 \\
\hline$X_{1}$ and $X_{3}$ & 169,05 & 6 & 28,18 & 1,53 & 2,09 \\
\hline$X_{2}$ and $X_{3}$ & 795,59 & 6 & 132,60 & 7,20 & 2,09 \\
\hline$X_{1}$ and $X_{2}$ and $X_{3}$ & 560,33 & 18 & 31,13 & 1,69 & 1,64 \\
\hline Error & 4423,21 & 240 & 18,43 & - & - \\
\hline
\end{tabular}


Table 9. Statistical parameters of regression equations

\begin{tabular}{c|c|c|c|c|c}
\hline \multirow{2}{*}{$\begin{array}{c}\text { Cement } \\
\text { sort }\end{array}$} & \multirow{2}{*}{$R$} & \multirow{2}{*}{$R^{2}$} & \multicolumn{3}{|c}{$\begin{array}{c}\text { Calculated values of } \\
\text { t-Student criteria }\end{array}$} \\
\cline { 4 - 6 } & & & $X_{1} X_{2}$ & $X_{2}^{2}$ & $X_{1}^{2} X_{2}$ \\
\hline $\mathrm{C} 1$ & 0,926 & 0,858 & 11,85 & 7,33 & 10,55 \\
\hline $\mathrm{C} 2$ & 0,867 & 0,752 & 8,26 & 4,44 & 7,67 \\
\hline $\mathrm{C} 3$ & 0,908 & 0,824 & 10,40 & 6,52 & 6,52 \\
\hline
\end{tabular}

Considering the values of multiple correlation coefficient $R$ and determination coefficient $R^{2}$ (Table 9), it can be concluded that the model chosen is correct. The calculated values of t-Student criteria $t_{c a l}$ are bigger than the critical value $t_{0,05}=2,00$ [21], thus all interactions of factors have significant effect on output parameter.

\section{Interpretation}

In order to make the test results interpretation easier, the relationships obtained can be presented graphically in the form of isolines. The isolines of compressive strength for cement $\mathrm{C} 2$ concrete are shown in Fig 12.

a)

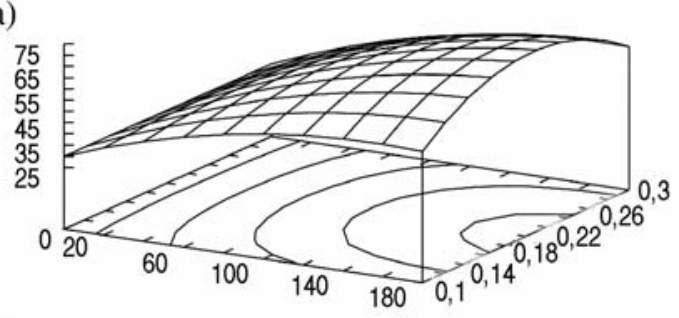

b)

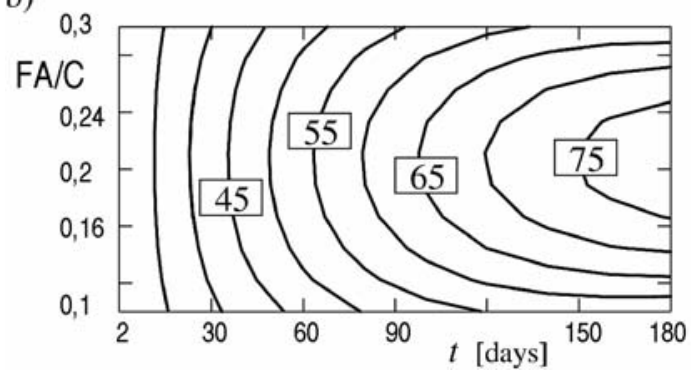

Fig 12. Graphical presentation of the response surface (a) and isolines (b) for compressive strength of $\mathrm{C} 2$ cement concrete
The analysis of relation $f_{c}=f(\mathrm{FA} / \mathrm{C}, t)$ for concretes made with 3 cements used showed that only time influences compressive strength development at early ages. The fly ash has a distinct effect on the increase in strength only about 60 days of storage. The highest value of compressive strength can be expected for FA/C value in the range of $0,18-0,24$, which can be observed after 90 days of curing.

The regression equations make the estimation of concrete strength development possible and in this way allow choosing the optimal composition of concrete for specific applications.

The practical method of evaluation of the quality of the model is comparing the values of a particular property calculated from the model to those determined by the experiment [23]. The comparison of the experimental values of compressive strength and the corresponding values predicted by models is presented in Fig 13 .

It could be seen that there exists a relatively strong correlation between the experimental and the theoretical values of compressive strength even though the concretes were examined at different ages. The strength of correlation increases with age, reflecting the delayed contribution of fly ash to compressive strength development. The linear relationships have been found (Fig 13) with the regression coefficients of 0,970 for cement $\mathrm{C} 1$ concretes, 0,911 for cement $\mathrm{C} 2$ concretes and 0,932 for cement $\mathrm{C} 3$ concretes.

\section{Conclusions}

The aim of this study was to assess the fly ash concrete strength development. The pozzolana and hydraulic activity of fly ash have mainly been pointed out as well as the possibility to use this addition as a concrete component. The fly ash addition, in considered range of FA/C values, has no significant effect on specific gravity and water absorbability of concrete but the addition reduces the capillary suction of water. The test results show that finally all mixes, containing fly ash, were able to develop a higher flexural strength than the control mixes $(\mathrm{FA} / \mathrm{C}=0)$.
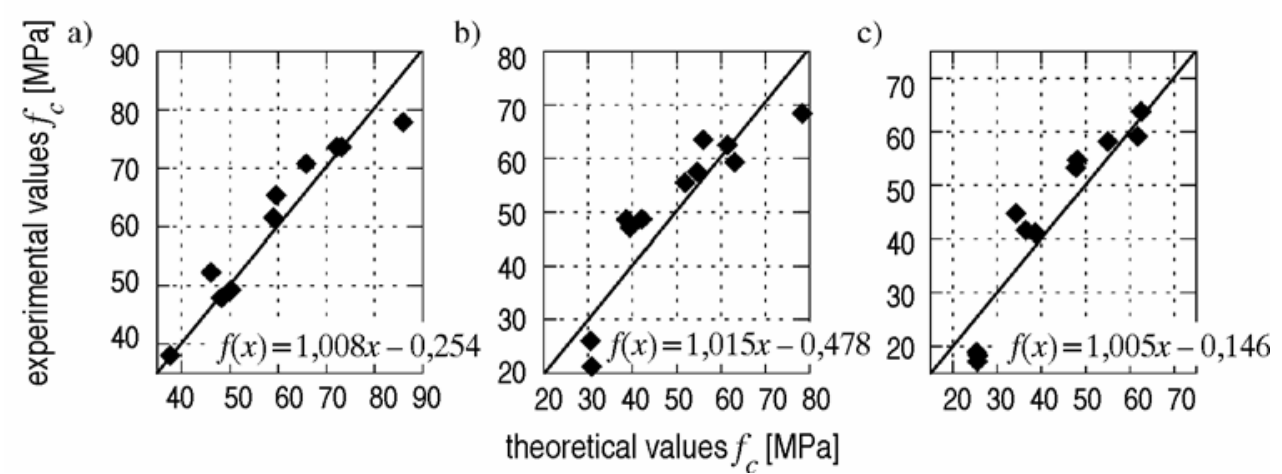

Fig 13. Comparison between experimental and predicted values of compressive strength: a) cement $\mathrm{C} 1$ concretes, b) cement $\mathrm{C} 2$ concretes, c) cement $\mathrm{C} 3$ concretes 
The results obtained show that the fly ash has a beneficial effect on compressive strength of all cements tested. Although the rate of strength increase of fly ash concrete is slower and sustains for longer periods, the concretes containing fly ash are capable of developing a higher strength than portland cement concrete as well as the blastfurnace cement concrete. After 180 days of storage the concretes containing $20 \%$ of fly ash, related to cement mass, gained a compressive strength about $25 \%$ higher than the concrete without addition, for all types of cement.

Statistical methods can be used to investigate the selected range of binders combinations (cement and fly ash) influence on chosen performance characteristics of concrete. Elaborated and verified statistical models can serve as a tool for estimating the compressive strength development of concrete according to fly ash content (in the range tested) and time of curing as well to identify the optimum binder content. The knowledge of basic properties of fly ash is fundamental to their effective usage in building industry.

\section{References}

1. AHMED, I. Use of waste materials in highway constructions. Noyes Data Corporation, New Jersey, 1993. 114 p.

2. CHANDRA, S. Waste materials used in concrete manufacturing. Noyes Publications, 1997. $651 \mathrm{p}$.

3. GUERRERO, A.; GOÑI, S.; MACÍAS, A. and LUXÁN, M. P. Mechanical properties, pore size distribution, and pore solution of fly ash-belite cement mortars. Cement and Concrete Research, 1999, 29(11), p. 1753-1758.

4. KÖNIG, G.; STARK, J.; KRUMBACH, R.; FRIEDEMANN, K.; SEYFARTH, K. and HEINRICH, U. Durability investigations of high performance concrete. In Proc of the $6^{\text {th }}$ International Symposium on High Strength/High Performance Concrete, Leipzig, 16-20 June 2002, p. 1107-1117.

5. URBAN, M. Properties of hardened self-compacting concrete with fly ash. In Proc of $3^{\text {rd }}$ International Scientific Conference Quality and Reliability in Building Industry, Levoca, 22-24 Oct 2003, p. 533-538.

6. FELDMAN, R. F.; CARETTE, G. G. and MALHOTRA, V. M. Studies on mechanism of development of physical and mechanical properties of high-volume fly ash-cement pastes. Cement and Concrete Composites, 1990, 12(4), p. $245-251$.

7. ANTIOHOS, S.; MAGANARI, K. and TSIMAS S. Evaluation of blends of high and low calcium fly ashes for use as supplementary cementing materials. Cement and Concrete Composites, 2005, 27(3), p. 349-356.

8. RUDZIONIS, Z. and IVANAUSKAS, E. Investigations in properties of self-compacting concrete modified by fly ash admixture. In Proc of the $8^{\text {th }}$ International Conference Modern Building Materials, Structures and Techniques, Vilnius, 19-21 May 2004. Selected papers, ed by E. K. Zavadskas, P. Vainiūnas and F. M. Mazzolani. Vilnius: Technika, 2004, p. 151-156.
9. SWAMY, R. N. Holistic design of concrete technology: the only route to durability and sustainability in construction. In Proc of $2^{\text {nd }}$ International Symposium on Cement and Concrete Technology in the 2000s, Istanbul, 6-10 Sept 2000, p. 58-72.

10. GANESH BABU, K. and NAGESWARA, Rao G. S. Early strength behaviour of fly ash concrete. Cement and Concrete Research, 1994, 24(2), p. 277-284.

11. GOLDMAN, A. and BENTUR, A. The influence of microfiller on enhancement of concrete strength. Cement and Concrete Research, 1993, 23(4), p. 962-972.

12. SENGUL, O.; TASDEMIR, C.; YUCEER, Z.; ERBAYDAR, M. and TASDEMIR, M. A. Mechanical behaviour of high strength concretes with high-volume fly ash. In Proc of the $6^{\text {th }}$ International Symposium on High Strength/High Performance Concrete, Leipzig, 16-20 June 2002, p. 1407-1420.

13. ONER, A.; AKYUZ, S. and YILDIZ, R. An experimental study on strength development of concrete containing fly ash and optimum usage of fly ash in concrete. Cement and Concrete Research, 2005, 35(6), p. 1165-1171.

14. CHINDAPRASIRT, P.; JATURAPITAKKUL, CH. and SINSIRI, T. Effect of fly ash fineness on compressive strength and pore size of blended cement paste. Cement and Concrete Composites, 2005, 27(4), p. 425-428.

15. HWANG, K.; NOGUCHI, T. AND TOMOSAWA, F. Prediction model of compressive strength development of fly-ash concrete. Cement and Concrete Research, 2004, 34(12), p. 2269-2276.

16. TANGPAGASIT, J.; CHEERAROT, R.; JATURAPITAKKUL, C. and KIATTIKOMOL, K. Packing effect and pozzolanic reaction of fly ash in mortar. Cement and Concrete Research, 2005, 35(6), p. 1145-1151.

17. PN-EN 450:1998. Fly ash for concrete - Definitions, requirements and quality control. Polish Committee for Standardization, Warsaw, Poland, 1998. 11p. (in Polish).

18. PN-EN 196-3:1996. Methods of testing cement - Part 3: Determination of setting time and soundness. Polish Committee for Standardization, Warsaw, Poland, 1996. 11 p. (in Polish).

19. EN 206-1: 2003 Concrete - Part 1: Specification, performance, production, and conformity. European Committee for Standardization, Brussels, Belgium, 2003. 101p.

20. PN-EN 12390-3:2002. Testing hardened concrete Part 3: Compressive strength of test specimens. Polish Committee for Standardization, Warsaw, Poland, 2002. 16 p. (in Polish).

21. BRANDT, S. Data Analysis. Statistical and computational methods for scientists and engineers. $3^{\text {rd }} \mathrm{ed}$, New York: Springer-Verlag, 1999. $730 \mathrm{p}$.

22. PERLMAN, G. The STAT Handbook. Data Analysis Programs on UNIX and MSDOS, 1986. $64 \mathrm{p}$.

23. BHANJA, S. and SENGUPTA, B. Investigations on compressive strength of silica fume concrete using statistical methods. Cement and Concrete Research, 2002, 32(9), p. 1391-1394. 


\section{BETONO SU LAKIAISIAIS PELENAIS STIPRIO AUGIMAS}

\section{Kosior-Kazberuk, M. Lelusz}

\section{S antrauka}

Remiantis eksperimentiniu tyrimu rezultatais, tobulinami betono mišinių su lakiaisiais pelenais stiprio augimo nustatymo matematiniai modeliai. Lakiųų pelenų kiekis mišinyje siekẻ iki $30 \%$. Pateikiami betono stiprio tyrimų rezultatai, esant skirtingiems cemento tipams (CEM I 42.5, CEM I 32.5, CEM III 32.5) bei mišinio kietejjimo laikui (2, 28, 90, 180 paros). Atlikta lakiųju pelenų kiekio, kietejimo laiko ir cemento tipo įtakos betono mišinio stipriui analizè. Gautų priklausomybių adekvatumo ịvertinimas atliktas statistiniais metodais. Pateikti rišamųjų medžiagų bei betono su lakiaisiais pelenais pagrindinių savybių eksperimentinių tyrimų rezultatai. Atlikta analizė parodè lakiųų pelenų taikymo betone privalumus.

Reikšminiai žodžiai: betonas, lakieji pelenai, gniuždomojo stiprio augimas, pucolaninè reakcija, statistiniai metodai, matematinis modelis.

Marta KOSIOR-KAZBERUK. Chair of Concrete and Masonry Structures, Dept of Civil and Environmental Engineering of Bialystok Technical University, (Poland), where she received her PhD degree. Member of Polish Ceramics Society. Her research interests include durability of building materials and structures with emphasis on diagnostic methods.

Małgorzata LELUSZ. Chair of Building Engineering and Prefabrication, Dept of Civil Engineering and Environmental Engineering of Bialystok Technical University (Poland), where she received her PhD degree. Member of Polish Ceramics Society. Her research interests include concrete technology and properties of building materials, particularly durability of materials. 